\title{
CULTURAL, MORPHOLOGICAL VARIABILITY RED ROT OF SUGARCANE IN SHAHJAHANPUR DISTRICT OF UTTAR PRADESH
}

\author{
VIKASH PANDEY \& D. N. SHUKLA
}

Bhargava Agricultural Laboratory, Faculty of Science, Department of Botany,

University of Allahabad, Allahabad, India

ABSTRACT
Sugarcane is an important cash crop and used as the chief source of sugar, grown in tropical and subtropical
region in India. Sugarcane production is challenged by various biotic and abiotic stresses, among the biotic factors, red
rot disease caused by Colletotrichum falcatum, is a major disease leading to severe reduction in sugarcane production.
Cultural, morphological studies conducted under, in vitro in Oat Meal Agar (OMA), showed characteristic variation in
their conidial and colony characters, which were five isolates collected from various places, in Uttar Pradesh. Thus, the
present study brings the cultural morphological variations and virulence characters, of C. falcatum.
KEYWORDS: Red Rot, Morphological, Variation, Sugarcane

Received: Jul 29, 2017; Accepted: Aug 18, 2017; Published: Sep 11, 2017; Paper Id.: IJASROCT201719

\section{INTRODUCTION}

Sugarcane (Saccharum officinarum L.), belong to the family Poaceae, is an economically important cash cum industrial crop, grown in the tropical and sub-tropical region in India. Many biotic and abiotic stresses affected sugarcane quality and yield. Sugarcane diseases caused by fungi, bacteria, virus and Mycoplasma, such as fungal diseases, become major problems for the sugarcane growing countries. Red rot's major fungal disease occur in all sugarcane growing states, in India. Red rot disease is the oldest serious fungal disease of sugarcane, generally called "Cancer" of sugarcane, and is caused by Colletotrichum falcatum, Went. Disease incidence depends upon the varieties, localities and favorable environmental condition. The disease was first described from Java (now Indonesia), by Went (1893), who called the fungus, C. falcatum and named the disease as "het rood snot", meaning "red smut". The sexual stage of C. falcatum was later reported by, Spegazzini (1896), in Argentina who named it Physalospora tucumanensis. Barber (1901), first observed this disease in Bihar (India), and Butler (1906) coined the name "Red Rot", the name by which it is known till date. Later, the red rot causal organism was reclassified by, Von Arx and Muller (1954), and included in the genus Glomerella, as G. tucumanensis. In India, the first documented epidemic of red rot, occurred in 1895-1901 and in subsequent years, a number of major outbreaks have been recorded, as a regular event in the sub-tropical and tropical regions of the country (Satyavir, 2003). This disease has been held accountable, for 5 to $10 \%$ cane yield and sugar recovery loss, worldwide. Red rot is considered as the major constraint for sugarcane production, in India (Viswanathan and Samiyappan, 2008). It has been reported as a damaging disease of sugarcane cultivars in Australia, Bangladesh, Pakistan, Taiwan, and USA (Viswanathan and Samiyappan, 2002). Red rot is widely distributed and has been reported in 68 sugar cane growing countries, of the world (Bharti et al., 2012). Red rot infection, in cane causes a loss of total weight to about $29.07 \%$, leading to $30.8 \%$ loss in sugar recovery (Hussnain and Afghan 2006). The present study conducts 
cultural and morphological variability of, $C$. falcatum, based on their conidial and colony characteristics. In the present study, an attempt has been made to collect five isolates of $C$. falcatum Went, prevalent in different sugarcane growing parts, in Pilibhit district of Uttar Pradesh in India.

\section{MATERIALS AND METHODS}

\section{Survey and Collection of Disease Samples}

An extensive survey of sugarcane growing areas, in various localities of Majhola, Pilibhit, Barkheda, Bisalpur and Puranpur in Pilibhit districts of Uttar Pradesh, were conducted during July and August months, of 2012-13. Varieties of sugar cane red rot disease symptoms, were collected for 27 isolates of C. falcatum. Strains were isolated from lesions on infected stem pieces. Symptoms of red rot disease, on these cultivars were recorded. Red rot infected sugarcane sample collected from directly farmer's fields.

Table 1: Source of Isolates Red Rot Disease

\begin{tabular}{|c|c|c|c|}
\hline Districts & Localities & Varieties & Isolates No. \\
\hline Shahjahanpur & Rosa & CoSe 98231 & CFSHARO \\
\hline Shahjahanpur & Tilhar & CoSe 92423 & CFSHATI \\
\hline Shahjahanpur & Nigohi & $\operatorname{CoS} 88230$ & CFSHANI \\
\hline Shahjahanpur & Puwayan & $\operatorname{CoS} 8436$ & CFSHAPU \\
\hline Shahjahanpur & Maksoodapur & $\operatorname{CoS} 8436$ & CFSHAMA \\
\hline
\end{tabular}

\section{Isolation of Colletotrichum Falcatum Went}

Infected canes were split open, by sterilizing knife and observed in reddish tissue and white transverse band. The red rot pathogen was isolated, by tissue segment methods as described by Rangaswami (1958), three 5-5 mm pieces of tissue were taken, from the margin of infected tissues, surface sterilized by dipping in 1\% sodium hypochlorite for $1 \mathrm{~min}$, immersed in 70\% ethanol for $1 \mathrm{~min}$ and rinsed three times, with sterilized water and finally dried in sterilized tissue paper (Abbas et al., 2010). After 5 days of incubation, the plates having red sporulation were purified by sub- culturing. All the isolates were further purified by single spore technique (Riker and Riker, 1936). The fungus from the pure cultures obtained, was examined microscopically, in order to match it with the characters of the pathogen, examined from the diseased samples. The pure cultures were maintained in Potato Dextrose Agar slants.

Samples were placed on water agar, and incubated at room temperature $\left(26\right.$ to $\left.31^{\circ} \mathrm{C}\right)$. The growing edges of any fungal hyphae, developing from the tissues were then transferred aseptically, to oatmeal agar medium and fungi were identified, following sporulation. Single spore subcultures were obtained, for each isolate using the procedure, described by Goh, (1999).

When the fungus showed sporulation, spore masses were pieced off with a sterilized weir loop and streaked on the surface of water agar. After inoculating overnight, at $29 \pm 2^{\circ} \mathrm{C}$ on biological oxygen demand (BOD), single germinated spores were picked with a sterilized needle and transferred to oat meal agar (OMA) medium. The cultures of different isolates were maintained, on OMA slants at $4^{\circ} \mathrm{C}$ for further studies.

\section{Morphological Characteristics}

Morphological characters of the colony viz., colony colour, substrate colour, margin of the colony and topography were recorded, through naked eye and spores viz., size, colour and shape of the conidia were observed in a binocular microscope, with oculars lens. The three replicate mean values examined and the range was determined. 


\section{RESULTS}

In order to find morphological variations of C. falcatum, among the different parts of Uttar Pradesh, an extensive survey was conducted, in major sugarcane growing areas of Uttar Pradesh, covering Pilibhit, Bisalpur, Puranpur, Barkheda, Pilibhit, 2012-2013.

\section{Cultural/Morphology Characteristic of Colletotrichum Falcatum}

The morphological characteristics of different isolates of $C$. falcatum, on OMA medium were studied; significant variations were observed, with respect to Conidial and Colony characteristic base.

Table 3: Conidial Characteristic of Colletotrichum Falcatum

\begin{tabular}{|l|l|l|l|l|}
\hline \multirow{2}{*}{ Isolates No. } & \multicolumn{4}{|c|}{ Conidial characteristics } \\
\cline { 2 - 5 } & $\begin{array}{c}\text { Length } \\
(\boldsymbol{\mu m})\end{array}$ & $\begin{array}{c}\text { Width } \\
(\boldsymbol{\mu} \mathbf{m})\end{array}$ & Colour & Shape \\
\hline CFSHRO & 25.2 & 3.8 & Hyaline & Falcate \\
\hline CFSHTI & 24.2 & 4.5 & Hyaline & Falcate \\
\hline CFSHNI & 25.2 & 4.4 & Hyaline & Falcate \\
\hline CFSHPU & 25.4 & 4.5 & Hyaline & Falcate \\
\hline CFSHMA & 24.5 & 4.3 & Hyaline & Falcate \\
\hline
\end{tabular}

The table shows that, the maximum conidial length of Colletotrichum falcatum was recorded, for strain CFSHMA as $24.5 \mu \mathrm{m}$, CFSHPU as $25.4 \mu \mathrm{m}, \mathrm{CFSHRO}$ and CFSHNI as $25.2 \mu \mathrm{m}$, whereas, the minimum colony growth of $C$. falcatum, was recorded for strain CFSHTI as $24.2 \mu \mathrm{m}$. The maximum conidial width of $C$. falcatum was recorded for strain CFSHTI and CFSHPU as $4.5 \mu \mathrm{m}$, which was followed by CFSHNI as $4.4 \mu \mathrm{m}$, CFSHMA as $4.3 \mu \mathrm{m}$, whereas the minimum colony growth of $C$. falcatum was recorded for strain CFSHRO, as $3.8 \mu \mathrm{m}$.

Table 3: Colony Characteristic of Colletotrichum Falcatum

\begin{tabular}{|l|l|l|l|l|l|l|}
\hline \multirow{2}{*}{ Isolates No. } & \multicolumn{1}{|c|}{ Colony Characteristics } \\
\cline { 2 - 7 } & $\begin{array}{c}\text { Colony } \\
\text { Colour }\end{array}$ & $\begin{array}{c}\text { Substrate } \\
\text { Colour }\end{array}$ & \multicolumn{1}{|c|}{ Margin } & \multicolumn{1}{|c|}{ Topography } & $\begin{array}{c}\text { Colony } \\
(\mathbf{m m})\end{array}$ & Sporulation \\
\hline CFSHRO & $\begin{array}{l}\text { Greyish } \\
\text { White }\end{array}$ & Black & Irregular & Raised Fluffy & 87.2 & +++ \\
\hline CFSHTI & Greyish & Greyish & Smooth & Raised Fluffy & 87.1 & +++ \\
\hline CFSHNI & White & White & Smooth & Raised Fluffy & 88.5 & +++ \\
\hline CFSHPU & Greyish & Black Greyish & Smooth & Raised Fluffy & 88.1 & +++ \\
\hline CFSHMA & Greyish & Black Greyish & Smooth & Raised Fluffy & 86.7 & +++ \\
\hline
\end{tabular}

The table shows that, the maximum colony of Colletotrichum falcatum, was recorded for strain CFSHNI as 88.5 $\mathrm{mm}$, which was followed by CFSHPU as $88.1 \mathrm{~mm}$, CFSHRO as $87.2 \mathrm{~mm}$, CFSHTI as $87.1 \mathrm{~mm}$, whereas the minimum colony growth of $C$. falcatum was recorded for strain CFSHMA as $86.7 \mathrm{~mm}$. The colony colour of $C$. falcatum was recorded for strain; CFSHRO Greyish white, CFSHTI, CFSHPU and CFSHMA Greyish, and CFSHNI White. The substrate colour of $C$. falcatum was recorded for strain; CFSHRO Black, CFSHTI Greyish, CFSHNI White, CFSHPU and CFSHMA Black Greyish.

\section{DISCUSSIONS}

Red rot caused by the fungus Colletotrichum falcatum, is dreadful and seed transmissible stalk disease, which spreads from place to place, through the infected sugarcanes (Ramesh Sundar et al., 2009; Malathi et al., 2010). The maximum conidial length of Colletotrichum falcatum, was recorded for strain CFSHMA as $24.5 \mu \mathrm{m}$, while the minimum 
conidial length of $C$. falcatum was recorded for strain CFSHTI, as $24.2 \mu \mathrm{m}$. The maximum conidial width of $C$. falcatum, was recorded for strain CFSHTI and CFSHPU as $4.5 \mu \mathrm{m}$, while the minimum conidial width of the C. falcatum was recorded for strain CFSHRO, as $3.8 \mu \mathrm{m}$. The maximum colony of Colletotrichum falcatum was recorded for strain CFSHNI as $88.5 \mathrm{~mm}$, while the minimum colony growth of $C$. falcatum was recorded for strain CFSHMA, as $86.7 \mathrm{~mm}$. The colony colour of $C$. falcatum was recorded; greyish white, greyish, and white. The substrate colour of $C$. falcatum was recorded for strain; black, greyish, white, and black greyish. On the basis of the cultural characters of $C$. falcatum, Abbott (1938) distinguished two races-a light producing white to light-grey, cottony mycelia, and a dark one with compact, velvety, dark-grey mycelia. Morphological diversity has been found, in four isolates of C. falcatum from SPF234, CO1148, BF162 and SHF242 (Abbas et al., 2010). Variability in cultural and morphological characters, and virulence and development of physiological races has been attributed to hybridization, mutation conidial and hyphen fusions (Bharti et al., 2011). Morphological variation revealed that, there exists a wide variation among the isolates, which is the basic method for characterization of different thirty isolates (Prema et al. 2013). Similar results have been obtained, by Malathi et al. (2011), in a study with a large number of isolates, and the growth of isolates has a direct correlation with pathogencity and it revealed that, the tropical isolates were light colored, fast growing and highly sporulating types. Prema et al. (2011), observed wide variation in C. musae isolates, with respect to cultural and morphological characters, the isolates produced blackish white, light pink and dark orange coloured colonies. Chona and Srivastava (1960), sub-divided each of these two races into groups and sub-groups, based on the texture of the mycelium and the degree of sporulation. They found that, isolations made from diseased canes from localities affected by the red rot epidemic, invariably yielded light, highly sporulating strains, whether isolated from the diseased stalk or midrib lesions and the dark sparsely sporulating isolates were only rarely encountered, in epidemic areas. In a recent study, two types of colony morphology were classified, in which the light type was observed more frequently, than the dark type in 15 isolates of Thailand (Sangdit et al., 2014). The light type was isolated from the stalks of sugarcane, in both localities affected and not affected by the red rot epidemic. However, the dark type could be isolated from the midrib lesions and stalks of sugarcane, $\mathrm{x} 5$ and was found only in localities without the red rot epidemic. Red rot morphological characterization, the 15 isolates reported in the current study had conidial size differences from previous reports. Sutton (1992) reported that the conidial size of $C$. falcatum ranged between 15.5 and $26.5 \mu \mathrm{m}$ in length and from 4 to $5 \mu \mathrm{m}$ in width. Kalaimani (1995) examined six isolates of $C$. falcatum and found variation in the length and width between 30.62 to $37.65 \mu \mathrm{m}$ and 6.69 to $8.46 \mu \mathrm{m}$, respectively. Mishra and Behera (2009a) revealed significant variation in the size of conidia of $C$. falcatum from India, where the dimensions varied between 23.94 and $30.83 \mu \mathrm{m}$ in length and from 3.28 to $3.69 \mu \mathrm{m}$ in width. The current study found the length of the conidia of the 15 isolates varied between 21.42 and $28.56 \mu \mathrm{m}$ which was less than in the earlier findings of Kalaimani (1995) and Mishra and Behera (2009a). In addition, the width of the conidia of the 15 isolates varied between 2.38 and $4.76 \mu \mathrm{m}$ which were shorter than in the previous reports by Sutton (1992), Kalaimani (1995) and Mishra and Behera (2009a). All 15 isolates were examined for the shape and size of appressoria. Sutton (1968) reported the appressorial size of an isolate of $C$. falcatum ranged between 6 to $21 \mu \mathrm{mm}$ in length and from 6 to $17 \mu \mathrm{m}$ in width. Crouch et al. (2009) described the appressorial size ranging between 10.25 and $14.0 \mu \mathrm{m}$ in length and from 7.25 to $10.5 \mu \mathrm{m}$ in width. Prihastuti et al. (2010) reported differences in the size of conidia (16-35 $\mu \mathrm{m}$ long, 4-5 $\mu \mathrm{m}$ wide) and appressoria (7$14.5 \mu \mathrm{m}$ long, 6.5-11.5 $\mu \mathrm{m}$ wide). The appressorial size of the 15 isolates reported in the current study ranged between 10.68 and $16.02 \mu \mathrm{m}$ in length and from 8.01 to $13.35 \mu \mathrm{m}$ in width; these dimensions were within the range of appressorial size recorded by Sutton (1968). 


\section{CONCLUSIONS}

The length of the conidia ranged from 24.5 to $24.2 \mu \mathrm{m}$. The width of the conidia ranged from 4.5 to $3.8 \mu \mathrm{m}$. Conidia was falcate shaped, with a round apical end tapering towards the base. The colony radial growth ranged from 88.5$86.7 \mathrm{~mm}$. Different colony colours viz., greyish white, greyish, and white colours were observed. All the isolates showed variation, regarding substrate colour, margin, topography, colony diameter and sporulation. Morphological variability depends on environmental condition and survey localities, in different sugar mills command area, in Shahjahanpur district of Uttar Pradesh.

\section{ACKNOWLEDGEMENT}

We are thankful to our Supervisor Prof. D.N. Shukla, Department of Botany, Faculty of Science, University of Allahabad, Allahabad, India, for Providing Laboratory Facilities, and we also thank the Department of Science and Technology, New Delhi, India, for providing financial assistance during the course of this study.

\section{REFERENCES}

1. Abbas, H. Anwar, S.A. Javed, N. Iqbal, M. And Abid, N. (2010). Morphological variability among isolates of Colletotrichum falcatum went; infecting four cultivars of sugar cane. Pak. J. Phytopathol. 22(2): 101-104.

2. Arx, Jav. And Mueller, E. (1954). Beitr. Kryptogamenf1.Schweig. 11: 195-196.

3. Barber, C.A. (1901). Sugarcane Diseases in Godavari and Ganjam districts. Madras Dept. Land Records and Agric. v. 2, Bull. 43: $181-194$

4. Bharti, Y.P. Kumar, A. Verma, V. Vishakarma, S.K. Sharma, M.L. Sharma, D.D.K. Harit, V.K. Yadav, V.K. And Shukla, D.N. (2011). Cultural and morphological variability among isolates of C. falcatum Went infecting cultivars of sugar cane from Uttar Pradesh. Proceeding of the 4th IAPSIT, International Sugar Conf. 469 - 476.

5. Bharti, Y.P. Vishwakarma, S.K. Kumar, A. Singh A. Sharma, M.L. And Shukla, D.N. (2012). Physiological and Pathological Aspects of Some New Isolates of Colletotrichum falcatum Causing Red Rot Disease in Saccharum spp Complex. Acta Phytopathologica et Entomologica Hungarica, 47(1): 35-50.

6. Butler, E.J. (1906). Fungus diseases of Sugar Cane in Bengal. Mem. Dept. Agr. India, Bot. Ser. 1: 1-53. (Red rot. 2-24).

7. Chona, B.L. And Srivastava, D.N. (1960). Variations in Colletotrichum falcatum Went, the causal organism of red rot of sugar cane. Indian Phytopathol. 13: 58-65.

8. Goh, T.K. (1999). Single spore isolation using a handmade glass needle. Fungal Divers, 2: 47-63.

9. Hussnain, Z. And Afghan, S. (2006). Impact of major cane diseases on sugarcane yield and sugar recovery. Annual Report, Shakarganj Sugar Research Institute, Jhang, 78-80.

10. Kalaimani, T. (1995). Morphological variation of six isolates of Colletotrichum Falcatum Went. The incidence of sugar cane red rot. Indian Sugar, 45: 505-508.

11. Malathi, P. Viswanathan, R. Ramesh Sundar, A. Padmanaban, P. Prakasam, N. Mohanraj, D. And Jothi (2011). Phylogenetic analysis of Colletotrichum falcatum isolates causing red rot in sugar cane. J. Sugarcane Res. 1(1): 69-74.

12. Malathi, P. Viswanathan, R. Ramesh Sundar, A. Prakasam, Padmanaban, P. Jothi, R. Renuka Devi S.R. And Poongothai, M. (2010). Variability among Colletotrichum falcatum patho types used for screening red rot resistance in Sugarcane. 
Sugarcane Intl. 28(2): 47-52.

13. Mishra, M.K. And Behera, B. (2009). Morphological variability among isolates of Colletotrichum falcatum Went. Causing red rot of sugar cane. J. Plant Prot. Environ. 6: 90-94.

14. Prema, R.T. Prabakar, K. Mohammed, F.P. Kathikeyan, G. And Raguchander, T. (2011). Morphological and Physiological Characterization of Colletotrichum musae the Causal Organism of Banana Anthracnose. World J. Agric. Sci. 7(6): 743-754.

15. Prema, R.T. Raguchander, T. And Kalaimani T. (2013). Morphological characterization and reaction of partial purified toxin of sugar cane red rot pathogen Colletotrichum falcatum collected from Southern India. International Journal of Agriculture sciences, 3 (10): 59-76.

16. Prihastuti, H., L. Cai, J.A. Crouch, S. Phoulivong, M.A. Moslem, E.H. C. Mckenzie And K.D. Hyde. (2010). Neotypification of Colletotrichum falcatum, the causative agent of red-rot disease in sugarcane. Sydowia, 62: 283-293.

17. Ramesh Sundar, A. Viswanathan, R. And Nagarathinam, S. (2009). Induction of systemic acquired resistance (SAR) using synthetic signal molecules against Colletotrichum falcatum in sugar cane. Sugar Tech. 11(3): 274-281.

18. Rangaswami, G. (1958). An agar block technique for isolating soil microorganisms with special reference to Pythiaceous fungi. Science and Culture, 24: 85 .

19. Riker, A.J. And Riker, R.S. (1936). Introduction to research on plant diseases. John Swift Co., St. Louis, Chicago. 117.

20. Sangdit, P. Leksomboon, C. And Lertsrutaiyotin, R. (2014). Cultural, Morphological and Pathological Characterization of Colletotrichum falcatum Causing Red Rot Disease of Sugarcane in Thailand. Kasetsart J. (Nat. Sci.), 48: 880 - 892

21. Satyavir, S. (2003). Red rot of Sugarcane-Current Scenario. Indian Phytopathol, 56 (3): 245-254.

22. Spegazzini, C. (1896). Rev. Fac. Agron. Y. Vet. 2: 227-228.

23. Sutton, B.C. (1992). The genus Glomerella and its anamorph Colletotrichum, 1-26. In J.A. Bailey and M.J. Jeger, (eds). Colletotrichum: Biology, Pathology and Control. Redwood Press Ltd, Melksham.

24. Vishwanathan, R. And Samiyappan, R. (2002). Induced systemic resistance by fluorescent Pseudomonas against red rot disease of sugarcane caused by Colletotrichum falcatum Went. Crop Protection, 21: 1-10.

25. Vishwanathan, R. And Samiyappan, R. (2008). Bio-formulation of fluorescent Pseudomonas spp. Induces systemic resistance against red rot disease and enhances commercial sugar yield in sugar cane. Archives of Phytopathology and Plant Protection, 41 (5): $377-388$

26. Went, F.A.F.C. (1893). Het Rood Snot. Arch. Java. Suikeridustrie, 1, pp. 265-282 